\title{
Hemiptera of Iraq. IV. Heteroptera, the aquatic and subaquatic families, Saldidae and Leptopodidae
}

\author{
Rauno E. Linnavuori
}

Linnavuori, R. E. 1994: Hemiptera of Iraq. IV. Heteroptera, the aquatic and subaquatic families, Saldidae and Leptopodidae. - Entomol. Fennica 5:8795.

A list of the species of the aquatic and subaquatic Heteroptera and Saldidae and Leptopodidae known to occur in Iraq is published. The list contains several new records for Iraq. Hebrus syriacus Horváth from Israel is redescribed.

Rauno E. Linnavuori, Somersoja, FIN-21220 Raisio 22, Finland

Received 26 April 1993, accepted 30 April 1993

Unlike the terrestrial Heteroptera the aquatic and subaquatic families and Saldidae and Leptopodidae have been thoroughly treated in Brown (1953), Cobben (1985), Jaczewski (1964), and Wróblewski (1962). Despite this, an extensive amount of material collected by me during my stay in 1979-1981 at the Ministry of Agriculture in Iraq contained several species new to Iraq. Most species belong to the Mediterranean and European, or the Syrio-Anatolian, Caucasian and Irano-Turanian elements. In contrast, the influence of the Paleotropical, Ethiopian and Eremian elements is relatively low. Two species, Hydrometra monoceros Linnavuori and Macrosaldula inornata Cobben, are endemics.

\section{Family Corixidae}

\section{Subfamily Micronectinae}

Micronecta (Dichaetonecta) pusilla (Horváth, 1895)

Recorded from Askikalak on the Great Zab River (Wróblewski 1962).

Distribution: SE Europe and SW Asia.
Micronecta (Dichaetonecta) isis Horváth, 1899

Material: Numerous exx from Baghdad, IV-V.1980; Al Kabaish, 27-28.VI. 1980; Safwan, 13.IV.1980; Sarsang, 25-28.VIII.1980, Linnavuori.

Biology: Very common in the immense marsh area $\mathrm{Al}$ Kabaish.

Distribution: Widespread in the Ethiopian Region. Also known from Egypt, the Arabian Peninsula and Israel.

Micronecta (Micronecta) anatolica Lindberg, 1922

Recorded from Askikalak on the Great Zab River (Wróblewski 1962).

Distribution: The Caucasus area, Turkey, Yemen, and S Asia as far as Vietnam.

\section{Subfamily Cymatiainae}

Cymatia rogenhoferi (Fieber, 1864)

Material: Baghdad, 1 ex, VI-VII.1980; Diyala-Mandali, several exx, 29.IX.1979, Linnavuori. Also recorded from 10 km NW of Baghdad, on the highway to Ramadi (Jaczewski 1964).

Biology: In pools with scanty vegetation.

Distribution: Pontomediterranean. 


\section{Subfamily Corixinae}

\section{Corixa affinis Leach, 1817}

Recorded from Babylon near Hilla and Shahraban, between Baquba and Khanaqin (Jaczewski 1964), and Baghdad, Baquba, Musayib, and Ramadi (Brown 1953).

Distribution: Holomediterranean.

Corixa jakowleffi (Horváth, 1880)

Recorded from Baghdad and Babylon near Hilla (Jaczewski 1964).

Distribution: Known from the Caucasus, Asia minor and areas S and SE from the Aral Sea.

\section{Heliocorisa vermiculata (Puton, 1874)}

Material: Numerous exx from Abu Ghraib, 3.IV.1953, A. Issa; Amara, 24.X.1979; Ana-Al Qaim, 5.V.1980; Baghdad, VI-VII.1980; Basra, 25-29.VI.1980; DiyalaMandali, 20.IX.1979; Al Kabaish, 26-28.VI.1980; NajafShabakah, 30.IV.1980; Safwan, 13.IV.1980; Tharthar lake, 27.VII.1978, Linnavuori. Recorded from several localities by Brown (1953) and Jaczewski (1964).

Biology: Common in pools, lakes and rivers. Often at lamps.

Distribution: Holomediterranean, extending to SW Asia and the coasts of the Caspian Sea.

\section{Hesperocorixa occulta Lundblad, 1929}

Material: Shaykh Addi, several exx, 11.V.1981; Zawita, 2 exx, 15.XI.1979, Linnavuori. Recorded from Shahraban, between Baquba and Khanaqin (Jaczewski 1964).

Biology: In pools and rivulets in hilly areas of northern Iraq.

Distribution: Besides Iraq, recorded from Turkestan, Afghanistan and Tibet.

Sigara (Pseudovermicorixa) nigrolineata nigrolineata (Fieber, 1848)

Material: Many exx from Shaykh Addi, 11.V.1981; Zawita, 25.XI.1979, Linnavuori.

Biology: Together with the preceding species.

Distribution: European, also known from N Africa and SW Asia.
Sigara (Sigara) albiventris (Horváth, 1911)

Askikalak on the Great Zab and the highway from Erbil to Mosul, a female probably of this species (Jaczewski 1964).

Distribution: Syrio-Anatolian.

Sigara (Sigara) assimilis (Fieber, 1848)

Material: Al Hadr, numerous exx, 6-7.V.1981; Safwan, 1 ex, 13.IV.1980, Linnavuori. Recorded from the vicinity of Baghdad and Hilla (Jaczewski 1964) and Masthal Ponds (Brown 1953).

Biology: At lamps.

Distribution: Pontomediterranean.

Sigara (Subsigara) samani tigranes Jansson, 1986

Baghdad (Jansson 1986).

Distribution: Syrio-Anatolian, known from Syria, Turkey, Iraq, and Iran.

Sigara (Tropocorixa) hoggarica Poisson, 1929

Material: Several exx from Diyala-Mandali, 23.IX.1979; Amara, 23-24.X.1979; Jalula, 27.XI.1979, Linnavuori. Recorded from Hilla and Shahraban (Jaczewski 1964).

Biology: In shallow pools and rivers.

Distribution: Saharo-Sindian, extending from Algeria and Mali to the Arabian Peninsula, Iran, Pakistan, and NW India.

Sigara (Vermicorixa) lateralis (Leach, 1817)

Material: Many exx from Amara, 23-24.X.1970; Baquba, 15.VII.1980; Basra, 12.IV.1980; Najaf-Shabakah, 30.IV-1.V.1980; Safwan, 13.IV.1980; As Salman, 18.IV. 1980; Sinjar, 7.V.1981; Zawita, 15.XI.1979, Linnavuori. Recorded from several localities in Brown (1953) and Jaczewski (1964).

Biology: In pools and rivers. Also at lamps. Distribution: Widely distributed in Europe, Africa, and SW, C and S Asia.

\section{Family Pleidae}

Plea minutissima Leach, 1817

Material: Amara, 8 exx, 24.X.1979; Sayid Sadiq, 4 exx, 11.VI.1980, Linnavuori. Recorded from several localities in Brown (1953) and Jaczewski (1964). 
Biology: In pools and rivers with abundant vegetation.

Distribution: European.

\section{Family Notonectidae}

Anisops sardea Herrich-Schäffer, 1849

Material: Several exx from Amara, 23-24.X.1979; Basra, 12.IV.1980; Diyala-Mandali, 29.IX.1979, Linnavuori; Abu Ghraib, 23.VI.1958, collector unknown; Baquba, 15.VII.1980; Haifa'a M. Jalal; Hilla, 29.X.1956, W. Muneer. Baghdad (Brown 1953).

Biology: In pools with rich vegetation.

Distribution: Paleotropical.

Anisops debilis perplexa Poisson, 1929

Material: Amara, 5 exx, 23-24.X.1979; DiyalaMandali, 1 ex, 29.IX.1979, Linnavuori.

Biology: In pools and rivers with rich vegetation.

Distribution: Eremian, extending from North Africa to Iran.

Anisops crinita Brooks, 1951

Material: Amara, numerous exx, 24.X.1979; DiyalaMandali, 3 exx, 29.IX.1979, Linnavuori.

Biology: Together with the preceding species; very common near Amara.

Distribution: Oriental. Previously recorded from Saudi Arabia, Baluchistan, India, New Caledonia, and as an isolated find from Corfu.

\section{Notonecta viridis Delcourt, 1909}

Material: Abu Ghraib, 1 ex, 22.V.1950, collector unknown; Kardaga spring water, 4 exx, 11.VI.1979, R. T. Kasnaw; Shaykh Addi, many exx, 11.V.1980, Linnavuori. Recorded from Baghdad and Baquba (Brown 1953).

Biology: In pools and rivulets with rich vegetation.

Distribution: Holomediterranean.

\section{Notonecta maculata Fabricius, 1794}

Material: Khalakan, several exx, 12.VI.1980, R. T. Kasnaw; Shaykh Addi, 5 exx, 11.V.1980, Linnavuori.
Biology: Together with the preceding species in a rivulet near Shaykh Addi.

Distribution: Holomediterranean, with a wide range in Central Europe.

\section{Family Naucoridae}

\section{Subfamily Aphelocheirinae}

Aphelocheirus kolenatii Kiritshenko, 1925 Fig. 1

Material: Iraq: Basra, 1 ex, 27.VI.1980, Haifa T. Jalal. Turkey: Corum, Bogazkale, 1 ex, collector unknown, in coll. Linnavuori.

Description: Forma macroptera. Length 8.75$9.5 \mathrm{~mm}$. Subopaque. Dark brown. Eyes dark gray. Lateral margins of pronotum, basal part of costal margins of elytra and dorsal and ventral sides of connexivum narrowly pale yellowish. Membranes of elytra grayish brown. Rostrum and legs yellow-brown. - Body ovate, broadest in middle of abdomen. Hair covering fine, smooth, brownish. Upper surface uneven owing to dense puncturing and rugosities. Head $0.44 \times$ as broad as basal width of pronotum and $1.5 \times$ as long as median length of same; vertex convex, relatively shiny, finely and rather densely punctate, $1.7 \times$ as broad apically as basally; ocular index 1.83 . Pronotum $3.45 \times$ as broad as long in middle, lateral margins curved, strongly diverging caudad, flat, rugose, provided with a row of short stiff bristles, humeral angles rounded; middle of disc convex, sloping laterad, very densely rugose, sides subhorizontal, obsoletely punctate. Scutellum 1.5 $\times$ as broad as long, $1.24 \times$ as long as median length of pronotum, basal margin opaque, disc otherwise convex, densely punctate and rugose. Elytra extending slightly beyond tip of abdomen, costal margins strongly constricted at the level of apex of scutellum, clavus and corium very densely punctate and rugose. Connexivum broadly visible, finely rugose and punctate, apical angles of paratergites sharp, spine-like. Rostrum extending to middle coxae. Under surface finely microsculptured. Posterior margins of hind tibiae and tarsi with very long swimming hairs, those of hind tibia about $2.5 \times$ as long as tibial diameter. - Male genitalia in Fig. 1. 


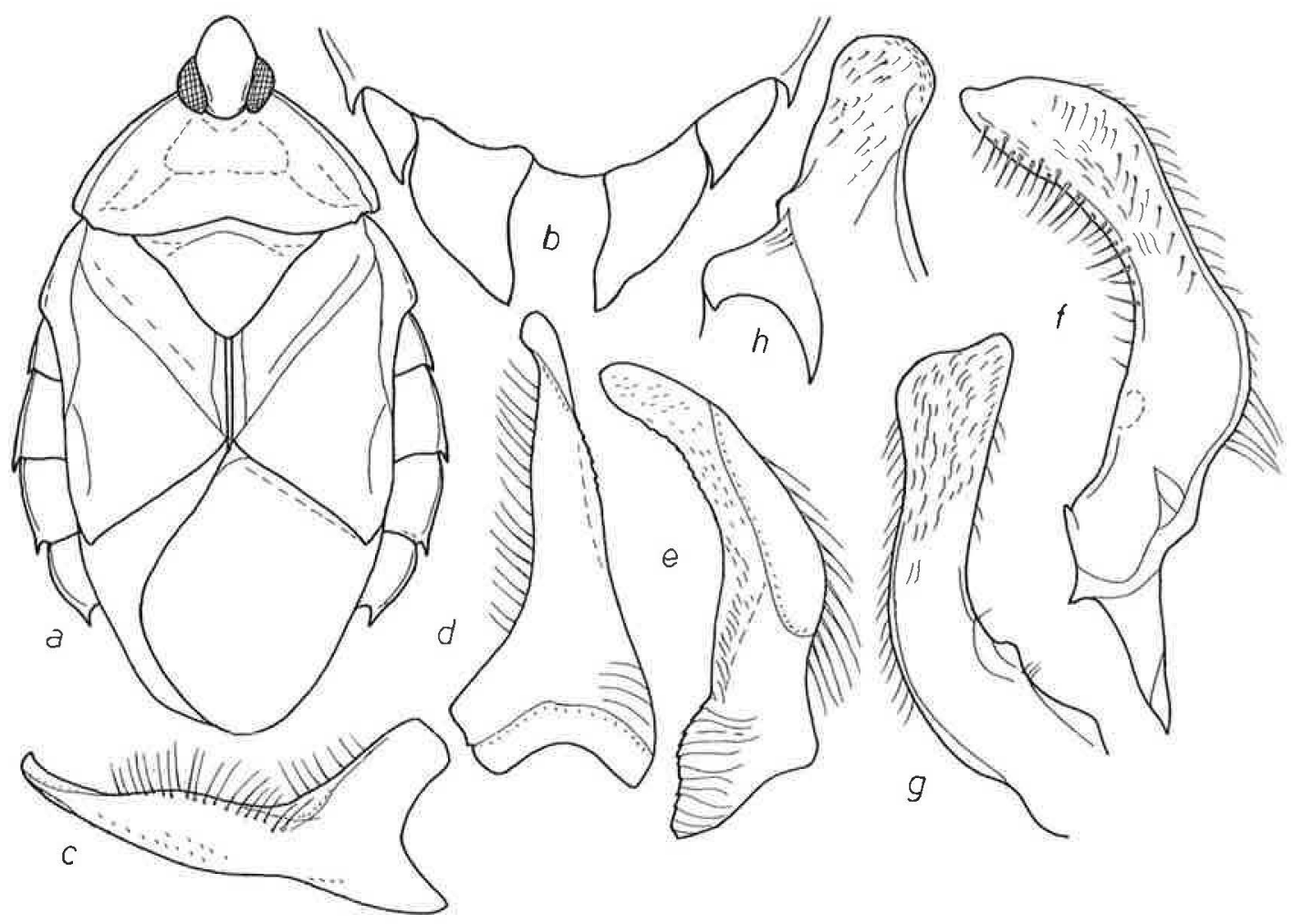

Fig. 1. Aphelochirus kolenatii Kiritshenko. a: male, dorsal view; b: apex of male abdomen; c-e: right style in different views; $f-g$ : left style in different views; h: basal process of left style.

Biology: At lamp, undoubtedly flying from the neighboring large river.

Distribution: Previously known from Caucasia. Dr. I. M. Kerzhner kindly compared the specimens with the holotype preserved in Mus. St. Petersburg.

\section{Family Belostomatidae}

\section{Lethocerus patruelis Stål, 1855}

Material: Many exx from Abu Ghraib, 6.XII.1966, S. Hassem; Baghdad, 3.IX.1960, collector unknown; Basra, 18.VI.1921, J. H. Campbell, 25.VI.1980, Linnavuori; A1 Kabaish, 27-28.VI.1980, Linnavuori; Kut, 23.VII.1968, M. Azhar; Nasiriya, 14.IX.1954, A. Isa.

Biology: At lamp; very common in Al Kabaish.

Distribution: Known from the Balkan Peninsula and SW Asia to SE Asia.

\section{Family Nepidae}

Subfamily Ranatrinae

Ranatra unicolor Scott, 1874

Fig. 2c-e

Material: Al Kabaish, 1 ex, 27-28.VI.1980, Linnavuori. Also recorded from Basra (Jaczewski 1964), and (as $R$. filiformis Fabricius, 1790) from Iraq, without data (Brown 1953).

Styles of $R$. unicolor and $R$. parvipes vicina Signoret, 1880 (Palestine, Egypt, the Ethiopian Region) are illustrated in Fig. 2a-b.

Biology: At lamp in the large marsh area, $\mathrm{Al}$ Kabaish.

Distribution: The Oriental Region, also known from Al Ayun in eastern parts of Saudi Arabia. 


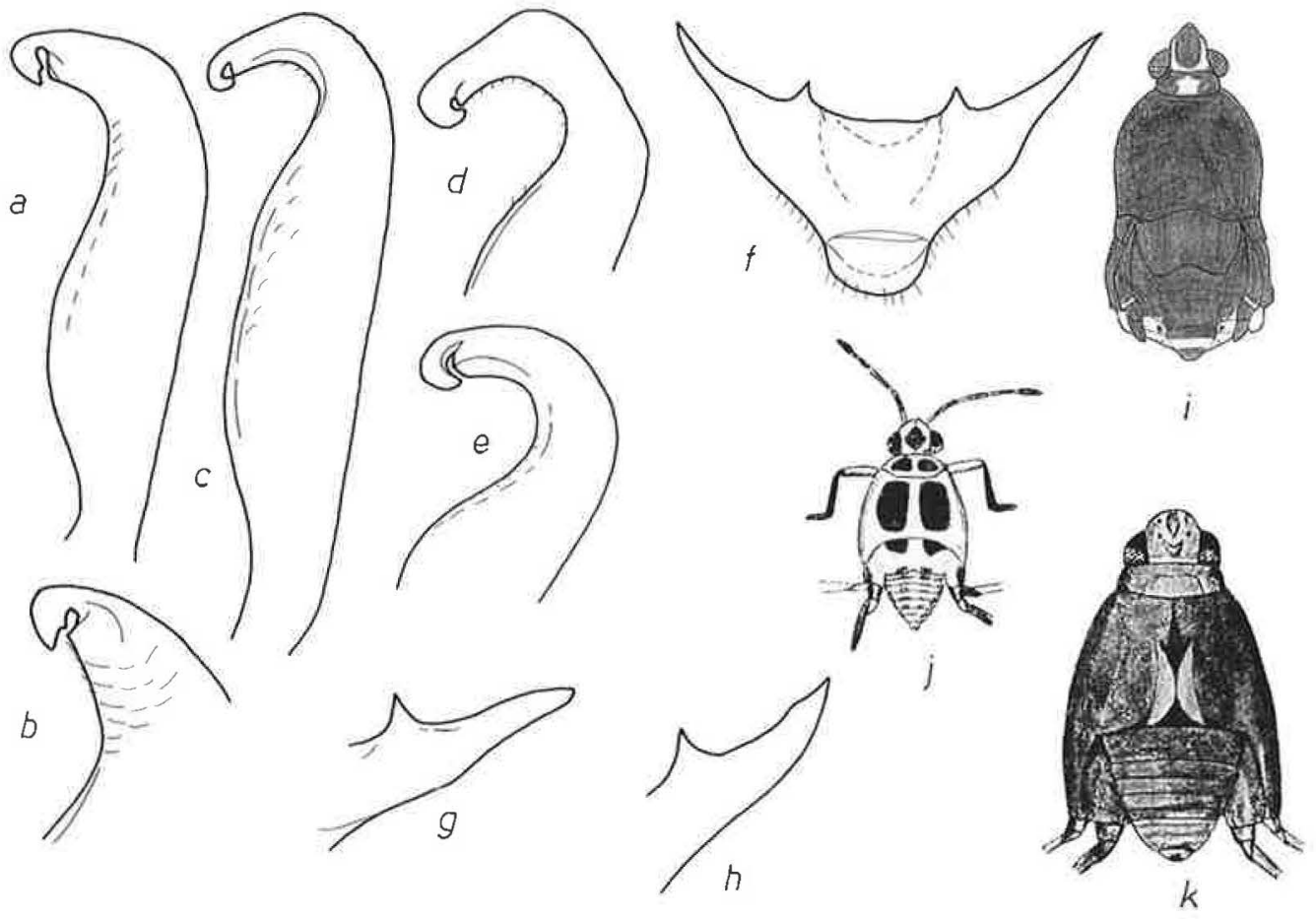

Fig. 2. Ranatra parvipes vicina Signoret (ex from Palestine). a-b: style. - $R$. unicolor Scott (ex from Al Kabaish). c: style; d-e: apex of style in different views. - Naboandelus bergevini bergevini Bergroth (ex from Al Kabaish). $\mathrm{f}$ : 10th male sternite; $\mathrm{g}-\mathrm{h}$ : lateral horn of 10th sternite in broad aspect ( $\mathrm{h}$ of ex from Egypt). i: female in dorsal view. - N. bergevini popovi Brown (from Palestine). j: nymph; k: female. — j-k after Lindberg 1923.

\section{Family Gerridae}

\section{Subfamily Gerrinae}

Gerris (Aquarius) paludum (Fabricius, 1794)

Material: Several exx from Ain Al Tamar, 20.X.1979, Linnavuori; Baghdad, 6.V.1969, L. Keder; Bitofi, 13.IX. 1971, J. Abdulla; Jalula, 27.VI.1979, Linnavuori; Kerbala, 11.III.1958, Salih. Recorded from Baghdad and Washash Creek in Brown (1953).

The specimens belong to the pale form $\mathrm{f}$. insularis Motschulsky, 1866 (= remigator Horváth, 1879, bergrothi (Lindberg, 1922), palmonii Wagner, 1954; synonymy after Kanyukova 1981:76-78).

Biology: In pools, brooks and irrigation canals.

Distribution: Euro-Siberian.
Gerris (Gerriselloides) kiritshenkoi Kanyukova, 1981

Fig. 3

Types: Caucasia, Alekseevka, 12 km SW Lenkoran, $\sigma$ paratype, 28.VI.1932, Znoiko, 우 paratype, 13.IX.1938, Veltištšev, in coll. Linnavuori.

Material: Caucasia: Talyš, Lenkoran, I o, 5.V.1909, Kiritshenko, in coll. Linnavuori. Iraq: Al Kabaish, 3 apterous $\wp$, 17-18.VI.1980, Linnavuori. Undoubtedly recorded as $G$. lacustris (Linnaeus, 1758) from Askikalak on the Great Zab and the highway from Erbil to Mosul in Jaczewski (1964).

The specimens studied are much narrower than the paratypes of $G$. kiritshenkoi. The pronotum, save a longitudinal median stripe, is deep black, while in kiritshenkoi the posterior part of the disc is dark reddish brown. The entire under surface is pale yellow, with only the lateral 


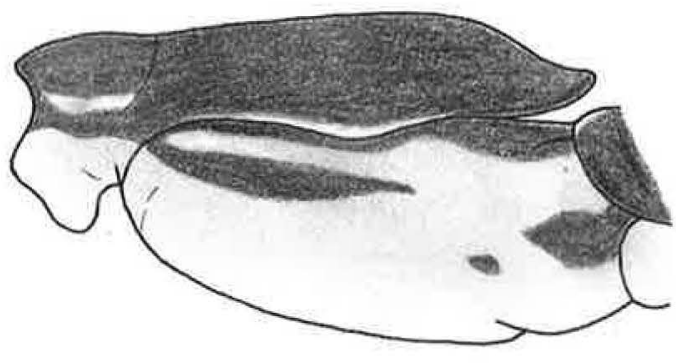

Fig. 3. Gerris kiritshenkoi Kanyukova (ex from Al Kabaish). Thorax in lateral view.

stripes and spots on the thorax and sublateral bands on the venter black. In G. kiritshenkoi the under surface, save trochanters and sides and apex of the venter, is black to blackish. Unfortunately the Iraqi specimens are females, and a complete comparison with $G$. kiritshenkoi is therefore not possible.

Biology: On open water in the marshes of $\mathrm{Al}$ Kabaish.

Distribution: Caucasian.

Gerris (Gerris) costae (Herrich-Schäffer, 1850)

Material: Shaykh Addi, 8 exx of the pale colored form f. fieberi Stichel, 1938, 11.V.1981, Linnavuori. Recorded from Ser Sing in Brown (1953). Iraq.

Biology: In a rivulet in hilly areas of northern

Distribution: Holomediterranean.

Gerris (Gerris) thoracicus Schummel, 1832

Material: Kardage spring well, 3 exx, 11.VI.1979, R. T. Kasnaw. Recorded from Suwara Tuka, source of Dohuk River and Baghdad in Brown (1953).

Distribution: Euro-Siberian.

\section{Gerris (Gerris) argentatus Schummel, 1832}

Material: Many exx from Amara, 23-24.X.1979; Jalula, 17.XI.1979; Sayid Sadiq, 11.VI.1980, Linnavuori; Shakbaba, 17.XI.1979, R. T. Kasnaw. Recorded from Askikalak on the Great Zab and the highway from Erbil to Mosul (Jaczewski 1964).

Biology: In brooks and pools with rich vegetation.

Distribution: European.

\section{Subfamily Halobatinae}

Metrocoris communis (Distant, 1910)

Euodus communis Distant 1910:151.

Metrocoris omanensis Brown, 1950:477-480 (Chen \& Nieser 1993:49-51).

Types: Oman, Ras-al-Khaima, 2 paratypes, 16.V.1949, G. Popov, in coll. Linnavuori.

Material: Shak-baba, numerous exx, 17.VI.1979, Linnavuori. Iran: near Kerman, 3 exx, 30.I.1901, Zarudny, in coll. Linnavuori.

Biology: In a brook with gravelly bottom.

Distribution: Previously known from Oman, Iran, Afghanistan and India.

\section{Subfamily Trepobatinae}

Naboandelus bergevini bergevini Bergroth, 1911 Figs. $2 \mathrm{f}-\mathrm{k}$

Material: Iraq: numerous exx from Amara, 2324.X.1979; Al Kabaish, 19-22.X.1979, 27-28.VI.1980, Linnavuori. Syria: Golan, 4 exx, J. Margalit. Egypt: Cairo, 3 exx, Patrizi. The Sudan: Northern Prov., Wadi Halfa, 1 ex, 14-17.X.1962, Linnavuori.

Description of the Iraqi populations: Forma aptera. Length or 1.8-2.0 mm, o 2.5-2.75 mm. Shiny black, with grayish tinge owing to dense smooth grayish tomentum. Lateral and basal margins of vertex, middle spot on pronotum and minute markings on apex of abdomen, pale. Eyes reddish gray. Antennae black, in $\sigma^{7}$ basal half of 1 st joint, in $q$ entire 1 st joint and base of 2 nd, yellowish. Under surface of head and prothorax in $\sigma^{7}$ pale yellowish, under surface in 0 largely pale. Legs black, fore coxae and trochanters and base of hind femora, pale. - Body elongate, relatively parallel-sided, about $2.2 \times$ as long as broad. With erect longish black bristles. Antennae long, in $0^{7}$ about $2.5 \times$, in $\subsetneq 2.1-2.3 \times$ as long as diatone, in $\sigma^{\top}$ relatively incrassate, in $q$ more gracile; proportions between joints 32:23:20:23 (diatone 43 units) (o), 32:24:19:21 (diatone 38 units) $\left(\sigma^{7}\right)$. - Male genitalia: 10th sternite in Fig. $2 \mathrm{f}-\mathrm{h}$.

Biology: Occurring in large groups on open water in the immense marsh area Al Kabaish.

Discussion: The taxonomy of $N$. bergevini is treated in Linnavuori 1971:360-361, 1975:45- 
46, and 1981:17-18. The Iraqi specimens resemble populations from Golan and Egypt in the dark coloring, save that the pale markings are somewhat more distinct. The size is also a little smaller; length of specimens from Cairo: ơ 2.2$2.4 \mathrm{~mm}$, o $2.8 \mathrm{~mm}$. Anyway, they undoubtedly belong to the nominate form, which in central and southern Palestine and SW Arabia is replaced by $N$. bergevini popovi Brown, 1951. That race is recognized by the paler coloring, in females especially, in which the mesonotum is ornamented with two longitudinal pale stripes as in Fig. 2j-k. Two further races are found in tropical Africa: $N$. bergevini pygmaeus Linnavuori, 1971, in the southern Sudan, and $N$. bergevini bouakeanus Linnavuori, 1975, known from the Ivory Coast, Nigeria, Upper Volta, Togo, Dahomey, Cameroon, and Chad.

N. signatus Distant, 1910, from India (material studied: South India, Karnataka, Tarikere area, 2 o $^{7}, 1$ o, 12-17.XI.1977, Zool. Mus. Copenhagen Exp., in coll. Linnavuori) also displays the general characters of $N$. bergevini. The 10th male sternite, for example, is similar. The specimens studied differ from $N$. bergevini in the bluish gray tinge in the coloring and the somewhat shorter antennae. In female especially, the antennae are remarkably short and gracile. $N$. signatus is apparently conspecific with $N$. bergevini, in which case it has the priority, of course. More material from India is needed for solving the problem.

\section{Family Veliidae}

\section{Subfamily Microveliinae}

\section{Microvelia gracillima Reuter, 1883}

Material: Baghdad, 1 ex, VI-VII.1980; Amara, 2 exx, 23-24.X.1979, Linnavuori.

Biology: Among vegetation in pools.

Distribution: The Ethiopian Region, Egypt, Palestine, the Arabian Peninsula, Madagascar.

Microvelia macani Brown, 1953

Microvelia hozari macani Brown 1953:584-586.

Microvelia perexigua Linnavuori 1960:54-56 (Linnavuori 1986:38 40).
Material: Many exx from Baghdad, IV-VII.1980; Amara, 23-24.X.1979; Jalula, 27.XI.1979; Samarra, 13.XI.1979, Linnavuori. Recorded from Baghdad (Brown: 1953).

Biology: Among vegetation in pools and brooks.

Distribution: Eremian with eastern distribution, known from southern Israel, Saudi Arabia and Iraq.

\section{Subfamily Veliinae}

Velia affinis Kolenati, 1856

Material; Many exx from Aznur, 28.V.1980; Darbandikhan, 16.V.1980; Joman, 6.VII.1975, R. T. Kasnaw; Kalak, 13.V.1981; Shaykh Addi, 11.V.1981, Linnavuori. Recorded from Ser Sing (Brown: 1953).

Biology: In rapid mountain brooks. At Kalak found under stones in a recently dried brook.

Distribution: Pontomediterranean.

\section{Subfamily Mesoveliidae}

Mesovelia vittigera Horváth, 1895

Material: Numerous exx from Amara, 22.X.1979; Jalula, 27.XI.1979; Al Kabaish, 22.X.1979, 26-28.VI.1980; Sayid Sadig, 11.VI.1980, Linnavuori. Recorded from Samarra (Jaczewski 1964).

Biology: Among vegetation in pools, brooks and marshes.

Distribution: Paleotropical.

\section{Subfamily Hebridae}

Hebrus pusillus arabicus Linnavuori, 1971

Material: Sayid Sadiq, I ex, 11.VI.1980, Linnavuori.

Biology: Among vegetation in a pool.

Distribution: Eremian, with eastern distribution; known from the Sudan (Port Sudan), Yemen and Saudi Arabia.

Hebrus syriacus Horváth, 1896

Fig. 4 dapest.

Type: Israel, Haifa, $q$ holotype, Reitter, in Mus. Bu- 

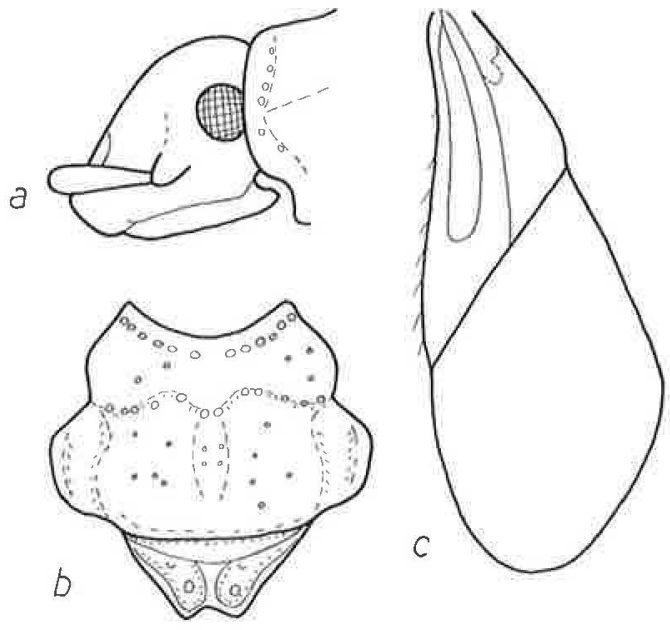

Fig. 4. Hebrus syriacus Horváth. a: head in lateral view; b: pronotum and scutellum; c: elytron.

Description: Length $1.6 \mathrm{~mm}$. Opaque. Reddish brown. Eyes brown. Elytra reddish brown; clavus with faint milky-brown basal spot extending to the level of apex of scutellum; membrane uniformly reddish brown without distinct pale pattern. Antennae and legs yellow-brown. Very small, narrow, body $2.7 \times$ as long as broad at base of pronotum. Hair covering short, concolorous. Head $0.66 \times$ as broad as basal width of pronotum, in apical view $1.18 \times$ as long as broad; vertex convex, in lateral view arising above anterior margin of pronotum; ocular index 2.43; bucculae as in Fig. 4a. Proportions between antennal joints 10:10:? (diatone 25.5 units). Pronotum $1.75 \times$ as broad as long in middle; lateral margins strongly insinuated in middle, strongly curved in apical portion, humeral angles roundedly prominent; puncturing on disc obsolete. Scutellum with distinctly bifid apex. Elytra distinctly shorter than abdomen, connexivum and apex of dorsum visible; length of elytron 55 , corium (measured from base to tip of costal margin) 34, and of membrane (measured from inner basal angle at tip of scutellum to apical margin) 41 units ( 1 unit $=0.015 \mathrm{~mm}$ ). Hind femora slightly curved, tibiae straight.

Distribution: The holotype is the only known specimen. Since all new finds from Israel belong to H. pusillus pusillus (Fallén, 1807), H. syriacus has possibly become extinct.

Discussion: $H$. syriacus is readily distinguished from $H$. pusillus and the related species by the smaller and narrower body, much narrower and more parallel-sided pronotum and, especially, the apically bifid scutellum.

\section{Family Hydrometridae}

Hydrometra stagnorum (Linnaeus, 1758)

Material: Sayid Sadiq, 2 exx, 11.VI.1960, Linnavuori. Recorded from Source of Dohuk River (Brown 1953).

Biology: Among vegetation in a pool.

Distribution: Euro-Siberian.

\section{Hydrometra monoceros Linnavuori, 1986}

Type: Basra, o paratype, 27.VI.1980, Haifa'a M. Jalal, in coll. Linnavuori.

Biology: At lamp.

Distribution: Also known from the Oasis Al Qatif in Saudi Arabia.

\section{Family Saldidae}

Macrosaldula inornata Cobben, 1985

Near Agra, Salta-ravin (Cobben 1985:232).

Distribution: Endemic.

Macrosaldula variabilis variabilis (HerrichSchaeffer, 1835)

Near Agra, Salta-ravin (Cobben 1985:232).

Distribution: Holomediterranean.

\section{Saldula misis Seidenstücker, 1964}

Material: Sawarah Tuka, 1 ex, 28.VIII.1980, Linnavuori.

Biology: At lamp in a wooded hilly locality in northern Iraq.

Distribution: Anatolian, previously known from Turkey.

Probably recorded as S. xanthochila (Fieber, 1859) in Stichel 1960:263. 
Saldula palustris (Douglas \& Scott, 1874) f. pallidipennis (Reuter, 1888)

Material: Several exx from Baghdad, VI-VII.1980; Samawah, 21.X.1979, Linnavuori.

Biology: At lamps.

Distribution: European, the pale form $\mathrm{f}$. pallidipennis Holomediterranean.

\section{Saldula pallipes (Fabricius, 1794)}

Recorded from Iraq in Stichel 1960:260. Distribution: Holarctic.

\section{Family Leptopodidae}

\section{Patapius spinosus (Rossi, 1790)}

Material: Baghdad, several exx, V-VII.1980, Linnavuori.

Biology: At lamps.

Distribution: Holomediterranean.

\section{References}

Brown, E. S. 1950: A small collection, mostly aquatic, from Oman. - Ann. Mag. Nat. Hist. (12)3:474-480.

- 1953: Notes on aquatic Hemiptera from Syria and Iraq. - Ann. Mag. Nat. Hist. 12(6):579-600.

Chen, P. P. \& Nieser, N. 1993: A taxonomic revision of the Oriental water strider genus Metrocoris Mayr (Hemiptera, Gerridae). Part II. - Steenstrupia $19(2): 45-82$.
China, W. E. 1938: Hemiptera from Iraq, Iran, and Arabia. - Zool. Ser. Field Mus. Nat. Hist. Chicago 20:427437.

Cobben, R. H. 1985: Additions to the Eurasian Saldid fauna, with a description of fourteen new species (Heteroptera, Saldidae). - Tijdschr. Entomol. 128(4):215-270.

Distant, W. L. 1910: Some undescribed Gerrinae. - Ann. Mag. Nat. Hist. (8) 5:140-153.

Jaczewski, T. 1964: Notes on some aqutic and semi-aquatic Heteroptera from Iraq. - Bull. Acad. Polon. Sci. 12:263-268.

Jansson, A. 1986: Sigara (Subsigata) samani tigranes ssp. n. (Heteroptera, Corixidae) from SW Asia. - Ann. Entomol. Fennici 52:137-138.

Kanyukova, E. V. 1981: Water-striders (Heteroptera, Gerridae) of the fauna of the USSR. - Trudy Zool. Inst. Akad. Nauk SSSR 105:62-93.

Lindberg, H. 1933: Über das V. Jugendstadium von Cylindrostethus bergrothi Lindb. und Naboandelus bergevini Bergr. sowie Beschreibung des Weibschens der vorstgenannten Art. (Hem. Gerridae). - Notulae Entomol. 13:43-47.

Linnavuori, R. E. 1960: Hemiptera of Israel I. - Ann. Zool. Soc. Zool.-Bot. Fennici Vanamo 22(11):1-71.

- 1971: Hemiptera of the Sudan, with remarks on some species of the adjacent countries. I. The aquatic and subaquatic families. - Ann. Zool. Fennici 8:340-366.

- 1975: Studies on African Heteroptera. - Tijdschr. Entomol. 118(2):43-65.

- 1981: Hemiptera of Nigeria, with remarks on some species of the adjacent countries. I. The aquatic and subaquatic families, Saldidae and Leptopodidae. Acta Entomol. Fennica 37:1-39.

- 1986: Heteroptera of Saudi Arabia. - Fauna of Saudi Arabia 8:31-197.

Stichel, W. 1960: Illustrierte Bestimmungstabellen der Wanzen. II. Europa 3:209-263. - Berlin-Hermsdorf.

Wróblewski, W. 1960: Notes on some Asiatic species of the genus Micronecta Kirk. (Heteroptera, Corixidae) III. - Bull. Acad. Polon. Sci. 10:33-37. 